TARNOWSKIE STUDIA TEOLOGICZNE 36 (2017) NR 2, S. 183-191

http://dx.doi.org/10.15633/tst.2623

ks. Tomasz Rąpała ${ }^{1}$

TARNÓW

\title{
Duchowa sylwetka alumna Jana Ślęzaka na podstawie notatek rekolekcyjnych z lat 1935-1937
}

„W całym życiu mieć przed oczyma to, że mam obowiązek zostać świętym i dążyć do tego z żelazną konsekwencją". Te słowa alumna Jana Ślęzaka wytyczają duchowy profil człowieka zakochanego w Bogu, a przez to zakochanego w człowieku. One ukazują zakorzenione w sercu głębokie pragnienia młodego człowieka, który odkrywa swoje powołanie i realizuje je w sposób radosny, entuzjastyczny i z przejęciem. Te słowa, pochodzące $\mathrm{z}$ notatek rekolekcyjnych z 1936 roku, są zapisane jako postanowienie, których wypełnianie realizowało się zapewne w prozie codziennego życia alumna, a potem - jak się dowiadujemy ze świadectw - kapłana, wikariusza i proboszcza w Ołpinach. Są one ciekawe z tego powodu, że wyznaczają konkretny szlak życia, którego celem jest wieczność. Mając niejako przed oczyma ten cel - życie staje się pasmem ofiarowanej bezinteresownej miłości wobec drugiego człowieka. „Wiara w zmartwychwstanie - powie Joseph Ratzinger - jest centralnym elementem chrześcijańskiego wyznania wiary w Boga, wynika z samego pojęcia Boga"’3. Zatem widzimy, że Bóg przygotowywał serce młodego chłopca Jana do wielkich dzieł, które stały się udziałem jego codzienności. Tam, gdzie Bóg jest w centrum życia - tam życie staje się darem dla innych. Święty Paweł powie, że „nikt nie żyje dla siebie i nikt nie umiera dla siebie. Jeśli żyjemy, żyjemy dla Pana” (Rz 14, 7). To skoncentrowanie wszystkiego na osobie Jezusa Chrystusa uwidaczniało się w każdym aspekcie realizacji drogi powołania kleryka Jana.

1 Tomasz Rąpała - kapłan diecezji tarnowskiej, magister teologii duchowości, licencjat dogmatyki, ojciec duchowny w Wyższym Seminarium Duchownym w Tarnowie, kierownik duchowy współpracujący z Centrum Formacji Duchowej Salwatorianów w Krakowie, rekolekcjonista.

2 J. Ślęzak, Notatki rekolekcyjne alumna 1935-1937, Ołpiny 2016, s. 35.

3 J. Ratzinger, Śmierć i życie wieczne, Warszawa 2000, s. 114. 


\section{Chrystus - centrum życia}

Notatki rekolekcyjne, po które najlepiej sięgać przede wszystkim na modlitwie (bo trudno byłoby wniknąć sercem w ich "klimat duchowy”, czytając je przy kawie), pozwalają nam dotknąć serca alumna, dla którego Bóg stał się źródłem i centrum życia. Rekolekcje to czas szczególnego wyczulenia na sprawy duchowe, dlatego też należy je doceniać, choć nie należy ich przeceniać. Bo rekolekcje to nie cała nasza duchowość, lecz jej elementarny fragment, w którym ludzkie serce poprzez otwarcie na słowo Boga zostaje dotknięte i pobudzone do głębszych pragnień. Dobre rekolekcje ożywiają wiarę, przylgnięcie do osoby Jezusa Chrystusa. Wtedy właśnie obecność Boga staje się jeszcze bardziej wyraźna, można dostrzec to, co umyka w prozie codzienności, jako przejaw Jego działania pełnego łagodności i pokory. Mieć „przed oczyma obowiązek świętości” to znaczy zobaczyć wyraźniej cel swojego istnienia. Dostrzegamy w ten sposób, w jakich kierunkach alumn Jan odkrywał swoje miejsce w Kościele, pośród braci. Odkrywał to, ponieważ miał przed oczyma cel, którego się trzymał całe życie. Nie pozwolił się „wytrącić” z tej drogi, co świadczyło o głębokim zakorzenieniu w Bogu. Krótko mówiąc - widział, bo słuchał Boga. Miał „oczy, które widzą i uszy, które słyszą" (por. Mk 8, 18). Mógł pojąć tajemnicę ewangelicznych prostaczków, które są zakryte przed „mądrymi i roztropnymi” (Łk 10, 21). To zaowocowało w jego późniejszym kapłańskim życiu.

Z Notatek..., które są zapisem z rekolekcji seminaryjnych wynika, że był człowiekiem otwartym na formację, prostolinijnym, skromnym i pełnym zaufania do Boga, a przez to i do kościelnych przełożonych. „Blaskiem wiary - zapisywał - oświeceni spełniamy wiernie wolę Bożą, wyrażoną w przepisach woli przełożonych"4 Taką postawę może przyjąć tylko ten, kto ma serce pokorne i otwarte na działanie Ducha Świętego we wspólnocie Kościoła. Jest to bardzo ważna cecha, o której warto mówić w dobie chęci odrzucenia przez wielu różnorodnych form autorytetu. Absolutne skoncentrowanie na Bogu w życiu Jana, zależność od Niego - czego źródłem jest adoracja Najświętszego Sakramentu w jego życiu - stało się spoiwem, które z dnia na dzień kształtowało szlachetność jego relacji z bliźnimi. Wyczulenie na Boga to delikatność wobec człowieka. U naszego alumna Jana widać to bardzo wyraźnie. Realizował w ten sposób Boskie zamiary względem

4 J. Ślęzak, Notatki rekolekcyjne..., s. 22. 
niego, a nie własne projekty na życie. Zapisał, że „tabernakulum dla kapłana to ognisko, które całe jego życie ogrzewa, zespala, które czyni go świętym. Kapłan, który umiłował tabernakulum, nie załamie się" . Te słowa uwidaczniają kondycję duchową, która - że tak powiem - wyprzedza obecny czas. Alumn widzi dalej, czerpiąc ze skarbca zażyłości z Jezusem obecnym w Hostii.

Duchowy mistrz w rozeznawaniu duchów, Ewagriusz z Pontu pisał, że łagodność (cichość) jest „matką poznania”. Największą cnotą kontemplatyka jest bowiem - ujmując negatywnie - jego „wolność od gniewu” lub też - pozytywnie - łagodność. „Modlitwa wyrasta z łagodności i wolności od gniewu” ${ }^{\prime 6}$ Alumn Jan Ślęzak w swoich Notatkach... dość często zwracał na to uwagę. „Patrzeć na bliźnich - pisał - w duchu wiary to widzieć w nich Pana Jezusa. Bliźni stworzony jest na obraz i podobieństwo Boże, on też jest powołany i wybrany, a każdy bliźni na pewno lepszy ode mnie. Odnosić się do bliźnich z jak największą dobrocią, serce im okazywać [...]. A gdzie trudno już okazać dobroć, to zastąpić ją grzecznością, do grzeczności dodać milczenie"7. Te słowa są bardzo pięknym obrazem myślenia młodego kleryka, który w ramach seminaryjnej formacji kształtował charakter, opierając się na dobroci i łagodności Chrystusa. Światłem w rozeznawaniu prawdy o sobie były dla niego słuchanie słowa Bożego i adoracja Pana Jezusa w Najświętszym Sakramencie. Jako postanowienie z rekolekcji zapisał: „Pracować nad emocjami, ćwiczyć się w łagodności, cichości, cierpliwości”»"

\section{Zatopiony w Bogu}

Należy tutaj koniecznie zatrzymać się niejako przy źródle, z jakiego czerpał seminarzysta, odkrywając radość swego powołania. Była to oczywiście

\footnotetext{
5 J. Ślęzak, Notatki rekolekcyjne..., s. 40.

6 Większość ascetycznych dzieł Ewagriusza w wydaniu Migne’a przypisano mnichowi Nilowi Synaicie, stąd odsyłam do: S. Nilus abbas, De oratione tractatus, w: S.P.N. Nili abbatis, Opera quae reperiri potuerunt omnia, tomus unicus, accurante J.-P. Migne (Patrologiae Cursus Completus. Series Graeca, 79), Parisiis 1865, kol. 1165-1200; polski przekład: O modlitwie, w: Ewagriusz z Pontu, Pisma ascetyczne, t. 1, przekład zbiorowy, wstęp i oprac. L. Nieścior omI (Źródła Monastyczne, 18), Kraków 1998, s. 275-305; por. G. Bunge, Wino demonów, Kraków 2019, s. 59.

7 J. Ślęzak, Notatki rekolekcyjne..., s. 33.

8 J. Ślęzak, Notatki rekolekcyjne..., s. 22.
} 
modlitwa. Relacja z Bogiem jest fundamentem całego życia, określa ona także misję kapłana. Kardynał Joseph Ratzinger w jednej z homilii podczas święceń powiedział, że „w ostatnich latach nazbyt zapomnieliśmy, niestety, że pierwszą posługą diakona, kapłana i biskupa jest modlitwa za innych" " W Notatkach... kleryka Jana dostrzegamy właśnie, jak wielką rolę odgrywa modlitwa w codziennym życiu alumna, który patrzy na kapłaństwo w perspektywie, gdzie pierwszym i najważniejszym zadaniem księdza jest modlitwa. Zapisał tak: „Kapłan to mąż modlitwy. Życie kapłana to jedna, nie kończąca się modlitwa. Kapłan to pośrednik między Bogiem a ludźmi, który ma dla nich upraszać łaski. Stale więc modlitwa winna być na jego ustach, stale myśl wzniesiona do Boga. Przed każdą czynnością wzbudzona dobra intencja" ${ }^{\prime \prime}$. Myślę, że te słowa stanowią dla nas, dzisiejszych duszpasterzy ważny punkt do rachunku sumienia: czy nie gubimy po drodze pierwszego celu kapłańskiej misji. Czy w codziennym wyścigu z czasem nie ulegamy powierzchowności w duchowości, co staje się przyczyną niemal bezdusznego kultu, który zamiast przysparzać nowych uczniów, zniechęca? To ważne pytania, które odczytuję z duchowego rysu tarnowskiego seminarzysty, traktującego kapłaństwo jako najgłębsze zjednoczenie z Panem Jezusem, a przez to dzielenie się radością wiary ze spotykanym człowiekiem. Alumn naszego seminarium jest także znakiem dla ludzi świeckich, bo przecież kształtował się w konkretnym środowisku, rodzinie, oddziaływał na znajomych i tych, z którymi się spotykał, choćby w czasie przerw seminaryjnych. Duchowość kleryka to duchowość osoby świeckiej, zanim podejmie decyzję o odpowiedzeniu Jezusowi „tak” na Jego osobiste zaproszenie. Jego postać jest dla nas wszystkich zatem wzorem, że kiedy Jezus staje się pasją - idziemy w naszych powołaniach ku świętości, bo Bóg stanowi centrum wszystkiego.

$\mathrm{Na}$ uwagę zasługuje również to, że bliska relacja $\mathrm{z}$ Bogiem na modlitwie sprawiała, iż kleryk Jan odkrywał, jak ważne jest obdarowanie, którego doświadczamy od Boga. Człowiek wrażliwy na Boże sprawy jest wdzięczny za to, co Bóg daje. Widzi, że całe jego życie, każdy dzień jest darem dla innych. „Kapłan [...] powinien Boga przepraszać i dziękować Mu stale za Jego dobrodziejstwa ${ }^{11 ”}$ - zapisał. Jest to bardzo ważny akord stylu modli-

\footnotetext{
9 J. Ratzinger/Benedykt xvi, Nauczać i zgłębiać Boża miłość. Teksty wybrane, t. 1: Kapłaństwo, Lublin 2016, s. 106.

${ }^{10}$ J. Ślęzak, Notatki rekolekcyjne..., s. 34.

${ }^{11}$ J. Ślęzak, Notatki rekolekcyjne..., s. 17.
} 
twy, która nie zamienia się w „koncert życzeń”, ale jest pasmem uwielbienia i dziękczynienia, bo Bóg jest $z$ nami i nigdy nas nie opuszcza. To jest to widzenie Boga w historii swojego życia, w prozie dnia, w różnych sytuacjach, które stają się udziałem człowieka. Ksiądz najpierw sam musi spotkać Boga, żeby w taki sposób ukazywać Go innym. Seminarium duchowne jest miejscem, w którym poddanie się formacji zależy od spotkania Jezusa Chrystusa jako osoby. Wtedy życie kapłańskie jest drogą ciągłej formacji ucznia misjonarza - mówiąc językiem papieża Franciszka. Mówi papież: „każdy chrześcijanin jest misjonarzem w takie mierze, w jakiej spotkał się z miłością Boga w Chrystusie Jezusie"12. Możemy z pewnością powiedzieć, że Jan Ślęzak spotkał zmartwychwstałego Pana. Dlatego też jego późniejsze kapłaństwo było zaszczepianiem wiary jako zaufania do Mistrza z Nazaretu, ukazywaniem Jego stylu życia. Zapisał w notesie tak: „Kapłan musi odznaczać się wielką pobożnością: głoszący naukę, a sam nie żyjący według niej - to cymbał brzmiący, to największy faryzeusz, to burzyciel religii i Kościoła"' ${ }^{\prime 3}$. W tych mocnych słowach, na które zapewne zwracał uwage rekolekcjonista - młody kleryk odnalazł poruszenie Ducha Świętego, które rozpalało coraz większe pragnienie świętości - przylgnięcia do Pana.

\section{Jaka modlitwa, takie życie}

Wszystko wypływa z modlitwy. „Kapłan ma być mężem modlitwy: tyle jest wart, ile warta jest jego modlitwa" ${ }^{14}$. Słysząc takie słowa rekolekcjonisty, utożsamiał się z nimi, ponieważ odnajdywał w nich treść swojego życia kleryckiego. Z Notatek... tchnie w każdym punkcie wielkie pragnienie świętości, która realizuje się w byciu przy Jezusie i w posłudze drugiemu człowiekowi. Ważne są słowa, które zapisał podczas jednej z rekolekcyjnych konferencji na temat modlitwy, która musi być żywa. Co to znaczy? Nie chodzi o modlitwę $\mathrm{z}$ bezwiednym i bezmyślnym powtarzaniem słów. Pisze o modlitwie z całej duszy ${ }^{15}$. Czytając Notatki..., można zatem wnioskować, że chodzi o zaangażowanie duchowe, które rodzi pobożne odprawianie Eucharystii, dobre

\footnotetext{
${ }^{12}$ Franciszek, Adhortacja apostolska Evangelii gaudium, Kraków 2013, nr 120.

${ }^{13}$ J. Ślęzak, Notatki rekolekcyjne..., s. 37.

${ }^{14}$ J. Ślęzak, Notatki rekolekcyjne..., s. 37.

15 Por. J. Ślęzak, Notatki rekolekcyjne..., s. 30.
} 
przystępowanie do spowiedzi św. i Komunii świętej ${ }^{16}$. Zauważa, że doświadczenie Boga jest głębokie wtedy, gdy serce staje się świątynią, w której „musi być zawsze cisza, skupienie" ${ }^{\prime 17}$. W ten sposób naśladuje Jezusa, który modli się w ciszy i samotności. W Katechizmie Kościoła Katolickiego czytamy: „Jezus często usuwa się w ustronne miejsce, $w$ samotność, na górę, najchętniej nocą, aby się modlić (Por. Mk 1, 35; 6, 46; Łk 5, 16). W swojej modlitwie poleca On ludzi, ponieważ już w swoim wcieleniu w pełni przyjmuje człowieczeństwo, a ofiarując siebie samego, ofiaruje ludzi Ojcu. On, Słowo, które „przyjęło ciało”, w swojej ludzkiej modlitwie uczestniczy w tym wszystkim, co przeżywają "Jego bracia” (Hbr 2, 12); współcierpi z ich słabościami, aby ich z nich wyzwolić (Por. Hbr 2, 15; 4, 15). Ojciec posłał Go właśnie w tym celu. Jego słowa i dzieła są zatem widzialnym przejawem Jego modlitwy „W ukryciu” ${ }^{\prime 1}$. Życie alumna Jana jest naśladowaniem tej Jezusowej modlitwy.

Przeciwnikiem, przeszkodą tego skupienia jest nieumiarkowana wesołość, nieopanowanie języka i nieumartwienie oczu ${ }^{19}$. Zawraca więc uwagę na wewnętrzną dyscyplinę, ascezę ciała. Myślę, że sprowadza się to do zachęty, aby bronić się przed próżnością, bo wtedy zły duch ma duże pole do działania. Kleryk Jan to wyczuwa w swej duchowej wrażliwości. Wspomniany już Ewagriusz z Pontu zwracał uwagę, że demony są bystrymi i wytrawnymi obserwatorami naszych zachowań i nie ujdzie im nawet najmniejsze, dla nas samych całkowicie nieświadome poruszenie ${ }^{20}$. Odkrywając w sobie żywą obecność Boga, młody kleryk Jan zdaje sobie sprawę z ważności sakramentu pojednania i pokuty. Bardzo ceni łaskę uświęcającą, nazywając ją „skarbem nieocenionym” ${ }^{21}$. Można wszystko stracić - zapisał - ale gdy zachowa się łaskę, jest się najszczęśliwszym, najbogatszym. W łasce uświęcającej upatruje bardzo wyraźnie dziecięctwo Boże. Przejmujące są słowa: „raczej śmierć niż grzech”22.

Warto też zauważyć, że pojawiają się w zapiskach wzmianki na temat śmierci. Rekolekcjonista zapewne zwracał na to uwagę młodych alumnów. „W świetle gromnicy zobaczymy całe nasze życie, całą naszą nędzę, nasze

\footnotetext{
${ }^{16}$ Por. J. Ślęzak, Notatki rekolekcyjne..., s. 30.

${ }_{17}$ J. Ślęzak, Notatki rekolekcyjne..., s. 21.

${ }_{18}$ Katechizm Kościoła Katolickiego, Pallottinum 1994, nr 2602.

19 Por. J. Ślęzak, Notatki rekolekcyjne..., s. 22.

${ }^{20}$ Ewagriusz z Pontu, De oratione..., s. 74.

${ }^{21}$ J. Ślęzak, Notatki rekolekcyjne..., s. 41.

${ }^{22}$ J. Ślęzak, Notatki rekolekcyjne..., s. 41.
} 
niewierności, grzechy. Zobaczymy, że to życie było tak krótkie i że nie warto było poświęcić dla niego wieczności"23. To są bardzo ważne słowa, które zdradzają głęboki sposób patrzenia na rzeczywistość. Świadczą one - dla mnie osobiście - o prawdziwym przejęciu się Bogiem, który jest dawcą życia. Właśnie wtedy codzienność staje się dziękczynieniem za obdarowanie, alumn, kapłan spala się dla Boga i człowieka w Kościele. Ma głęboką świadomość swej misji, złożonej w sercu od wieków przez Stwórcę. Jego życie nie jest chybione, ale jest radosnym hymnem na cześć Zmartwychwstałego, jest drogą razem z Nim, „tym samym wczoraj, dziś i na wieki” (Hbr 13, 8).

Profilem duchowym seminarzysty w Tarnowie była także miłość do Matki Najświętszej. Widział w niej wzór zawierzenia Bogu, a także w niej upatrywał moc w drodze świętości. „Kapłan bez gorącego i naprawdę dziecięcego nabożeństwa do Matki Najświętszej nie może być dobrym kapłanem i utrzymać się przy świętości” ${ }^{24}$.

\section{Zakończenie}

Staraniem ordynariusza Kordoby bp. Demetria Fernándeza Gonzáleza ukazała się niedawno książka pt. Pisma do kapłanów autorstwa św. Jana z Àvili, doktora Kościoła. Był on księdzem diecezjalnym żyjącym w xvi wieku. W liście Do pewnego kaznodziei [Ludwika z Granady op] napisał słowa, które dobrze oddają styl duchowości alumna, wikarego i proboszcza w Ołpinach - Jana Ślęzaka: „Powinieneś więc, Wasza Wielebność, dla zadania do jakiego zostałeś wezwany, bardzo uważać, aby nie stłumić w sobie ducha synowskiego wobec Boga, Ojca wszystkich, i ducha Ojca wobec tych, których Bóg daje ci za dzieci. Dla tego pierwszego należy bardzo czcić ów najwyższy Majestat, adorując Go z bardzo głęboką pokorą, nie zważając na swój własny byt, lecz umieszczając go w niewysłowionej otchłani Jego bytu, i będąc Mu wiernym, szukając we wszystkim i przez wszystko Jego chwały [...]"25.

Ludzie o wielkich duchowych pragnieniach czerpią z jednego źródła - bliskości Boga. To pokazuje, że mimo wieków, odrębnych miejsc geograficznych, pragnienie świętości, postawienie Boga w centrum doświadczenia jest źródłem budzenia się nowych świętych, którzy zapaleni ogniem Ducha Świętego,

\footnotetext{
${ }^{23}$ J. Ślęzak, Notatki rekolekcyjne..., s. 31.

${ }^{24}$ J. Ślęzak, Notatki rekolekcyjne..., s. 51.

${ }_{25}$ Św. Jan z Ávila, Pisma do kapłanów, Poznań 2017, s. 350.
} 
słuchają i odpowiadają na to, co ustawicznie „Duch mówi do Kościoła” (Ap 2, 7.11.17.29; 3, 6.13.22). Przez to stają się wiernymi synami Kościoła przysparzającymi nowych uczniów misjonarzy (por. Mt 28, 19) Jezusa Chrystusa zmartwychwstałego, w którym „żyjemy, poruszamy się i jesteśmy” (Dz 17, 28).

Ksiądz Jan Ślęzak może być dla nas wzorem umiłowania Jezusa i Jego Kościoła, a także wychodzenia ku człowiekowi, który - jak pisał św. Jan Paweł II - jest „drogą Kościoła” ${ }^{26}$. Oto misja wszystkich, którzy przyjęli sakrament chrztu świętego i realizują go w różnych wymiarach codziennego życia.

\section{Bibliografia}

Ewagriusz z Pontu, O modlitwie, w: Ewagriusz z Pontu, Pisma ascetyczne, t. 1, przekład zbiorowy, wstęp i oprac. L. Nieścior omi (Źródła Monastyczne, 18), Kraków 1998 s. 275-305.

Franciszek, Adhortacja apostolska Evangelii gaudium, Kraków 2013.

Jan Paweł II, Encyklika Redemptor hominis, Poznań 1979.

Katechizm Kościoła Katolickiego, Pallottinum 1994.

Ratzinger J., Śmierć i życie wieczne, Warszawa 2000.

Ratzinger J./Benedykt XVI, Nauczać i zgłębiać Bożą miłość. Teksty wybrane, t. 1: Kapłaństwo, Lublin 2016.

Ślęzak J., Notatki rekolekcyjne alumna 1935-1937, Ołpiny 2016.

Św. Jan z Ávila, Pisma do kapłanów, Poznań 2017.

\section{Streszczenie}

Ksiądz Jan Ślęzak, proboszcz w Ołpinach był człowiekiem, który realizował powołanie w sposób radosny i bardzo ofiarny. Rozpalała go miłość do Boga, a poprzez to do drugiego człowieka. Był księdzem „z powołania” - zgodnie z określeniem, którego wierni używają w odniesieniu do księży, którzy są dla nich, a nie dla siebie.

Z Notatek rekolekcyjnych wiemy, w jaki sposób kształtował swe powołanie alumn Jan. Bardzo wyraźnie dostrzegamy jego zaangażowanie w formację ludzką, duchową i intelektualną. To właśnie w Seminarium Duchownym w Tarnowie odnalazł fundament na całe życie. Dlatego też posługa w parafii przynosiła tak wiele owoców.

${ }^{26}$ Jan Paweł II, Encyklika Redemptor hominis, Poznań 1979, nr 14. 
Ksiądz Jan Ślęzak wpisuje się w profil duchowy księdza diecezjalnego, który spala się w posłudze kapłańskiej dla wiernych, ogłaszając zmartwychwstałego Chrystusa. Tym profilem jest bycie dla ludu, bycie z ludem. I to ma najgłębszy sens.

\section{Słowa kluczowe}

duchowość, modlitwa, słowo Boże, adoracja, Eucharystia

\section{Summary}

\section{The Spiritual Profile of the Seminarian Jan Ślęzak Based on Religious Retreat Notes 1935-1937}

The spiritual notes of seminarian Jan Ślęzak need to be read during the prayer. As a result, it would be easier to understand their deeper meaning that grew in the heart of a young boy, the heart, which was filled with the desire for sanctity. This desire, as he used to say, needs to be achieved with "the iron discipline."

After a lecture of Notatki... we can see that he was open for the seminary formation and he had a vision of the future. Jan submitted himself to the Word of God and worshipped Jesus Christ present in the Blessed Sacrament. This was a source of his spiritual life that he was discovering when we was a seminarian and remained faithful to it till the end of his life. Consequently, his priestly service was so fruitful. Many testimonies of his parishioners are the evidence of his outstanding work.

A close relation with God in the prayer enabled seminarian Jan to discover very important issue: gifts that we receive from God. A person who is sensitive to God's matters is grateful for all that comes from God. The person sees that his whole life and each day is a gift for others.

A deeper look, which Jan had, is expressed in his notes on the topic of death. Life is a short period which we need to live in a total closeness to God. It means that death is a passage to the eternity, where the experience of God is in fullness of joy. A spiritual figure of Jan Ślęzak is an example for the present formation of seminarians. It is good to draw on the experience of people, for whom God was a center of every action.

\section{Keywords}

spirituality, prayer, Word of God, adoration, Eucharist 